\title{
The Dispute between Indonesia and the European Union Concerning the Export Ban on Nickel Ore under the International Trade Law
}

\author{
Reygina Yenny Mitrania ${ }^{1}$, Manotar Tampubolon ${ }^{2}$, Edward M. L. Panjaitan ${ }^{3}$ \\ \{reygina.mitrania@outlook.com ${ }^{1}$, justitie234@gmail.com ${ }^{2}$, e.labuan@gmail.com ${ }^{3}$ \}
}

Universitas Kristen Indonesia ${ }^{123}$

\begin{abstract}
The continual advances in technologies, inevitably increases the demand for Nickel worldwide, thus prompted the Indonesian government to take action in order to maintain the country's nickel resources and increase the added value of Nickel by issuing several regulations that limits nickel exports. This policy is detrimental for the EU whose nickel production relied on Indonesian mines selling raw minerals. EU then filed a lawsuit against Indonesia in the WTO. The purpose of this paper is to find out whether Indonesia's new regulations on nickel ore exports ban can be justified under the international trade law and its principles. The research methodology used is normative legal research. This study concludes that Indonesia doesn't violate the State Economic Sovereignty theory and the prohibition of quantitative restrictions principle given the current state of Indonesia does classify under the several exceptions of said principle.
\end{abstract}

Keywords: WTO, International Trade Law, the prohibition of quantitative restrictions

\section{Introduction}

In our everyday life, nickel is no longer a foreign thing. Nickel can be found nearly everywhere such as spoons, forks, knives, as well as other necessities such as batteries, and various types of electronic devices, including cellphones, laptops, and so forth. Known as "the mother of industry", nickel is one of the essential minerals used in various kinds of industrial sectors in the world. Nickel production is the main material in a wide range of production, including Stainless steels. According to mineral commodity summaries 2020, Indonesia ranks first in the world's largest nickel-producing country, followed by the Philippines, Russia, and New Caledonia [1].

Quoting from Investing News, in early 2019, Indonesia reported to have a domestic nickel industry that could soon overthrow palm oil, which is Indonesia's second largest export [2]. Thus, from all the data provided, despite Indonesia's rank as the world's largest nickel producing country, the contribution of nickel sales is neither as influential nor significant enough in Indonesia's economic growth. The reasoning behind this is mainly the fact that Indonesia mostly sales Nickel Ore causing lower selling price. With the supply amount of nickel that can be produced in Indonesia, it is highly unfortunate if the results of these very significant exports are not as profitable for Indonesia's economic growth.

According to Luhut Binsar Panjaitan as the coordinating minister for Maritime Affairs and Investment, the export ban could bring multiple benefits from the added value of nickel ore processing. Currently the price of exported nickel ore is only around US\$ 30 per ton, while 
if it is converted into ferronickel, it can increase the selling price to US\$ 100 per ton [3]. The nickel ore exports ban are also due to the development of Indonesia's technology enabling the processing of ferronickel. Currently, there are many nickel processing smelters that are already in operation and are also being built in Indonesia.

The nickel ore exports ban is certainly detrimental to countries that frequently import nickel ore, including the European Union. The European Commission, which coordinates trade policy in the 28-countries of the European Union, said these restrictions unfairly restricted EU producers' access to nickel ore.

On 22 November 2019, the European Union requested consultations with Indonesia regarding various measures concerning certain raw materials necessary for the production of stainless steel, as well as a cross-sectoral import duty exemption scheme conditional upon the use of domestic over imported goods. The request covers the following alleged measures: (a) restrictions on exports of nickel, including an actual prohibition to export; (b) domestic processing requirements for nickel, iron ore, chromium and coal; (c) domestic marketing obligations for nickel and coal products; (d) export licensing requirements for nickel; and (e) a prohibited subsidy scheme [4]. Therefore, exploring from both parties' perspectives, it is interesting to discuss the dispute between Indonesia and the European Union in the nickel ore exports ban under the international trade law.

\section{Research Methods}

\subsection{The Chronological Order of the Dispute Between Indonesia and The European Union Concerning the Export Ban on Nickel Ore}

Law of The Republic of Indonesia Number 4/2009 on Mineral and Coal Mining states that holders of IUP and IUPK are required to process and purify their mining products in the country. Purification must be carried out no later than five years after the law is enacted. However, this clause was then added three years after the issuance of the Government Regulation No. 1 of 2014 on the Second Amendment to Government Regulation No. 23 of 2010 on the Implementation of Mineral and Coal Mining Business, where it is stated that the holders of IUP and IUPK Production Operations are required to process and purify mining products domestically. which means that the selling of raw minerals abroad can only be carried out if they have been processed or have gone through a refining process domestically. As a result of this regulation, in a short time there was a significant issue in the nickel mining business involving several mining companies forced into shut down due to the high cost of building a smelter for the purifying processes.

The issuance of Government Regulation Number 1 of 2017 concerning the implementation of mineral and coal mining business activities led to regulations requiring IUP and IUPK permit holders, if they wish to export, to rely on the presence of smelters, which many permit holders do not have. The permit holders then have to build a new smelter for the refining process in order to export the existing minerals within five years. Knowing this, the ban on raw mineral exports should only be enforced in 2022. But then, Regulation No. 11/2019 by The Ministry of Energy and Mineral Resources was issued again, which ensures that the ban on exports of raw minerals will take effect starting January $1^{\text {st }}, 2020$.

The reason for this acceleration of the export ban on raw minerals is because the large surge of nickel ore exports from year to year has eroded the supply of Indonesia's nickel reserves. Data from the Ministry of Energy and Mineral Resources noted that the proven 
reserves of national nickel commodities reached 698 million tons. This amount will only be able to supply nickel ore for smelters for about 7,6 years.

On 22 November 2019, the European Union requested consultations with Indonesia regarding various measures concerning certain raw materials necessary for the production of stainless steel, as well as a cross-sectoral import duty exemption scheme conditional upon the use of domestic over imported goods. The request covers the following alleged measures: (a) restrictions on exports of nickel, including an actual prohibition to export; (b) domestic processing requirements for nickel, iron ore, chromium and coal; (c) domestic marketing obligations for nickel and coal products; (d) export licensing requirements for nickel; and (e) a prohibited subsidy scheme [5].

\section{Results and Discussion}

\subsection{State Economic Sovereignty Theory}

The term "sovereignty" is derived from the Latin word "Superanus", means supreme (the highest). Sovereignty is an important element for the State as a subject of international law. The concept of state sovereignty according to the Westphalian system is that the state has monopoly rights in exercising certain powers related to its territory and citizens. The Westphalian system still remain as the model for international politics around the world and the concept of state sovereignty, solidified by the peace, is still the basis for modem international treaties and conventions [6].

Sovereignty also means that the highest political authority rests in the State to regulate and determine itself. A sovereign state is an independent state that is not under the control of another state. According to Huala Adolf, the state's economic sovereignty is the highest power of the state to regulate economic policies within its territory or international economic policies [7]. Then according to Asif Qureshi, the state's economic sovereignty is the overall economic power of the state, including equality of status in international economic relations [8].

The economic power of the state is more related to the power of the state over its natural resources, the economic system, and the rules of agreements in international economic relations. The status equality is closely related to equality and state independence, including its rights and obligations. State's Economic Sovereignty is also stated in Article 33 paragraph (3) of the 1945 Constitution of the Republic of Indonesia, "The land, the waters and the natural resources within shall be under the powers of the State and shall be used to the greatest benefit of the people."

Adding to that, we can refer to Article 1 of the Law Number 11/1967 on the Basic Provisions of Mining that stated "All minerals found within the Indonesian mining jurisdiction in the form of natural resources as blessing of God Almighty are national wealth of the Indonesian people and shall, therefore, be controlled and utilized by the State for maximum welfare of the people." Then, in the general explanation section of Law number 11/1967, it is explained that, the state has complete control over all minerals for the sake of the comparison of the interests of the state and the prosperity of the people because these minerals are national wealth. The meaning of the sentence "the state has complete control" can be interpreted as the state, namely the government, has the authority to determine the use, utilization and rights of all natural resources, where the government has the authority to regulate, administer, manage, and also control the management and utilization of all the natural resources. 
Indonesia, as the subject of international law as well as the member of the WTO, is obligated to comply with all the regulations, agreements and all the principles of international law. Nickel, classifies as a non-renewable natural resource, also an essential commodity, which plays an important role in the provision of management industrial raw materials and important producers of foreign exchange. So it is appropriate that the needs are to be done as optimally as possible in order to be utilized for the welfare of the people.

The theory of the State economic sovereignty can be used because, quoting from what Huala Adolf said, the country has the highest power in regulating economic policy within its own territory. In the case of the EU's lawsuit against Indonesia over the ban on nickel ore exports, the State of Indonesia does not abuse its sovereignty given the fact that it is only banning something that it considers to be detrimental to the country if it is not enforced, and within its own territory, on its own natural recources. Indonesia, as a country that is entitled to its own economic sovereignty, certainly has the right to regulate what products is to be exported to other countries. In accordance with the fundamental concept of sovereignty stating that the State, within certain boundaries, has the right to exercise its sovereignty over persons, goods, and legal events occurring within its territory.

If we examine this dispute more deeply, with the exceptions in the prohibition of quantitative restriction principles that will be discussed later, Indonesia as a sovereign State, in its new regulations on the raw mineral export ban, clearly does not violate the principle of international law. Therefore, the enactment of regulations on the Export Ban on Nickel Ore by Indonesia can be justified by national law, international law and strengthened by the theory of economic sovereignty.

\subsection{The Prohibition of Quantitative Restrictions Principle}

GATT main objectives are: [9]

a. to help raise standards of living;

b. to achieve full employment;

c. to develop the world's resources;

d. to expand production and exchange of goods;

e. to promote economic development.

In order to achieve the four main objectives of GATT, there are five GATT principles:

1. Most-Favoured-Nation (MFN) Principle

2. National Treatment Principle

3. principle of reciprocity

4. Protection through tariffs only

5. The Prohibition of Quantitative Restrictions Principle

In here, we will be focusing on The Prohibition of Quantitative Restrictions Principle. This principle implies that each member state is prohibited to restrict import and export through quotas or license. But of course, this Prohibition of Quantitative Restrictions Principle has its own exceptions. Some exceptions for the prohibition of quantitative restrictions are:

1. Export prohibitions or restrictions temporarily applied to prevent or relieve critical shortages of foodstuffs essential to the exporting WTO Members (Paragraph 2 (a)) to protect domestic articles, especially those concerning agricultural and fishery products;

2. Import and export prohibitions or restrictions necessary to the application of standards or regulations for the classification, grading or marketing of commodities in international trade (Paragraph $2(\mathrm{~b})$ ); and 
3. Import restrictions on any agricultural or fisheries product, necessary to the enforcement of governmental Measures which operate to restrict production of the domestic product or for certain other purposes (Paragraph 2 (c)

4. Restrictions to safeguard the balance of payments (Article XII regarding all WTO Members; Article XVIII: B regarding developing WTO Members in the early stages of economic development);

Then, with the recognition in Article XVIII, in which these exceptions are extended further to countries that are still considered as developing countries. It should also be emphasized that these restrictions are not allowed to be carried out beyond what is necessary to protect the balance of payments. The restriction must also be reduced or even removed if the exception is no longer needed. This restriction is also carried out with the aim that developing countries can prevent the depletion of their foreign exchange caused by demand for imports needed for payment or because they are establishing or expanding their domestic production.

In Article XIII of the GATT regarding the Non-discriminatory Administration of Quantitative Restrictions it is stated that, "no prohibition or restriction shall be applied by any contracting party on the importation of any product of the territory of any other contracting party or on the exportation of any product destined for the territory of any other contracting party, unless the importation of the like product of all third countries or the exportation of the like product to all third countries is similarly prohibited or restricted." Thus, although allowed with certain exceptions, this quantitative restriction cannot be applied in a discriminatory manner.

The main purpose of this restriction for Indonesia (classifies as a developing country), is to help Indonesia not to deplete the country's foreign exchange caused by import demand (in this case, the European Union) where this quantitative restriction is necessary to establish and expand nickel production (smelter construction, etc.) in Indonesia. From the several existing exceptions to this Prohibition of Quantitative Restrictions Principle, Indonesia has clearly not violated, but is in accordance with the exceptions stated regarding this principle. Indonesia's current state is included in two of the four exceptions.

The first exception is in which stated that the exporting country can impose quantitative restrictions to prevent the depletion of essential products of the exporting country. In this dispute, Indonesia as a nickel ore exporting country can impose quantitative restrictions to prevent the depletion of Nickel, in which, nickel is included from this country's essential product, as nickel is needed for various purposes ranging from individual needs to large industries. Apart from that, the export of nickel must also be limited due to the fact that nickel is a non-renewable resource, which means that its existence is cannot be replenished by nature as quick as it is consumed. It is an element whose reserves will be depleted at some point and it will not be possible to get any more of it in the mid-term. In short, nickel comes directly from the earth and can run out at any time.

The next exception regarding this principle is the Quantitative restriction measures can be carried out if the exporting country does so to protect its (foreign) balance of payments (Article XII). Ways to improve a country's trade balance can be helped by improving the selling value of nickel by processing it first so that nickel becomes semi-finished goods, or ferronickel, or the level exceeds $0.7 \%$, causing it to have a higher selling price. The higher selling price will certainly increase the country's income. This increasing income will then affect the country's balance of payments, from deficit into a surplus. 


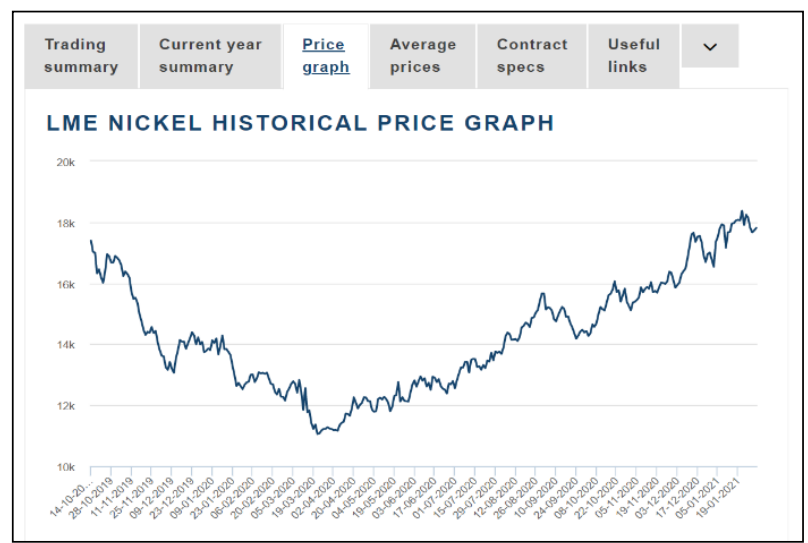

Fig 1. Nickel price commodity [10]

It can be seen from the graph that the prospect of nickel export prices in the future will continue to increase. The higher selling price in the future will result in an increase in state income. This increase in state revenue from nickel exports will greatly assist in influencing the increase in the country's balance of payments, which was previously in deficit to a surplus.

\section{Conclusion}

The nickel ore exports ban by Indonesia can be justified based on international trade law by referring to the State Economic Sovereignty theory and the exception of the principle of prohibition of quantitative restrictions. Where based on the theory of state economic sovereignty, the state has complete power in setting economic policy for its own country. The country's economic power includes the economic system, treaty agreements in international economic relations and its natural resources (in this dispute nickel).

Then, based on the exceptions of the prohibition of quantitative restrictions principle which states the exporting country can impose quantitative restrictions to prevent the depletion of essential products in the exporting country. Here, Indonesia as a nickel ore exporting country can carry out quantitative restrictions to prevent the depletion of Nickel which is an essential product of the state which also includes non-renewable mineral materials. Then exceptions to the prohibition of quantitative restrictions, namely exceptions to the prohibition of quantitative restrictions, can be made if the exporting country does so to protect its (foreign) balance of payments (Article XII)

\section{References}

[1] The General Agreement on Tariffs and Trade 1994

[2] Law Number 11/1967 on the Basic Provisions of Mining

[3] Law of The Republic of Indonesia Number 4/2009 on Mineral and Coal Mining

[4] The issuance of Government Regulation Number 1 of 2017 concerning the implementation of mineral and coal mining business activities

[5] Pubs.Usgs. Gov, 2020, https://pubs.usgs.gov/periodicals/mcs2020/mcs2020.pdf. accessed 1 November 2020. 
[6] Barrera, Priscila. "10 Top Nickel-Producing Countries | INN". https://investingnews.com/daily/resource-investing/base-metals-investing/nickel-investing/topnickelproducing-countries/. Diakses 2 November 2020.

[7] Pusat Data dan Analisa Tempo, 2020, Melihat Perkembangan Ekspor Nikel Nasional dan Permasalahanya, TEMPO Publishing, Jakarta, h. 63

[8] https://www.wto.org/english/tratop_e/dispu_e/cases_e/ds592_e.htm

[9] https://www.wto.org/english/tratop_e/dispu_e/cases_e/ds592_e.htm

[10] https://digitalcommons.lasalle.edu/cgi/viewcontent.cgi?article=1146\&context=the_histories

[11] Huala Adolf, 2006, Hukum Perdagangan Internasional, RajaGrafindo Persada, Depok, h.15

[12] https://docs.wto.org/gattdocs/q/GG/MGT/58-44.PDF

[13] "LME Nickel", https://www.lme.com/en-GB/Metals/Non-ferrous/Nickel\#tabIndex=0 di akses 5 November 2020

[14] Sinaga, Benny R. P., et al. (2020) Justice Reconception in Establishing Responsive Tax Law in Indonesia: A Rawlsian Perspective. Ayer Journal, Vol. 27, No. 3.

[15] Suhartono, Slamet dan Mokhamad Khoirul Huda (2019) The Exsistence of Tax Court in Indonesia Judicial System, Journal of Advanced Research in Law and Economics, Vol. IX, Issue 3 (41). 